DOI https://doi.org/10.36059/978-966-397-117-9/198-219

\title{
CUSTOMERS' RIGHTS PROTECTION IN THE FIELD OF INSURANCE SERVICES UNDER UKRAINIAN LEGISLATION
}

\section{Milovska N. V.}

Legal regulation of one or other civil legal contracts, including contracts on insurance service provision, provides its legal determination, differentiation of subject matter, consolidation of form, rights and obligations, their responsibility for non-execution of contract terms and conditions etc. Exercise of civil rights and performance of obligations are carried out in different ways and by using various means, in various scope and sequence, it is limited by different time limits in any aspects as well ${ }^{1}$.

Part 1 of Article 12 of the Civil Code of Ukraine (hereinafter - the CC of Ukraine) points to the possibility of a free exercise of a civil right at sole discretion. This means that all issues connected with the use of subjective rights, including the scope and ways of their exercise, are solved by competent persons at their sole discretion. As O. O. Kot mentions, discretion in the context of exercise of a subjective civil right provides for awareness of a goal and specific ways of its realization by a subject as well as conscious decision-making, namely, a choice of one of behavior option within an existing subjective right ${ }^{2}$.

A subjective civil right gives three opportunities to a competent person: firstly, the opportunity to take certain positive actions directly connected with the exercise of their fight; secondly, the opportunity to demand certain behavior from a person obliged directly; thirdly, the opportunity to appeal to the court with a claim to enforce a person obliged to execute their obligations or to protect a right from its violation from other person's side. In addition, O. O. Kot rightly notes, that exercise of a subjective right requires not only existence of this right but also a proper subject taking relevant actions ${ }^{3}$.

\footnotetext{
${ }^{1}$ Вахонєва Т. М. Строки (терміни) у цивільному праві: дис. ... канд. юрид. наук. К., 2005. С. 61.

2 Кот О. О. Здійснення та захист суб'єктивних цивільних прав: проблеми теорії та судової практики: монографія. К.: Алерта, 2017. С. 33.

3 Кот О. О. Здійснення та захист суб'єктивних цивільних прав: проблеми теорії та судової практики: монографія. К.: Алерта, 2017. С. 39.
} 
As it follows from Article 984 of the Civil Code of Ukraine, Article 354 of the Commercial Code of Ukraine and Article 16 of the Law of Ukraine "On Insurance", the parties to the insurance contract are the insurer and the insured. Civil legislation consolidates one of the basic principles arising from the method of civil law regulation, - legal equality of participants of personal non-property and property relations. Legal equality is in the fact that each party of civil relations has own set of right and obligations and is independent, not subordinated to others ${ }^{5}$.

In the field of insurance obligations, the principle of legal equality of participants in relevant legal relations is essential as well. However, in the practical aspect of this issue there may be a variety of deviations from the requirements of the legal equality principle. This is explained by the fact that the insurer as a professional participant in insurance relations can use own professional and economic potential to enforce the insured persons, who in the majority are economically weaker and less trained professionally, to agree to conditions proposed by the insurer, which are set in the text of an insurance contract and, of course, are more beneficial for the latter ${ }^{6}$. Therefore, in order to prevent violation of the parity (balance) of interests between the insurer and the insured persons, an insurance contract is concluded on the basis of insurance rules, which, despite the fact that they are developed by the insurer independently, are subject to approval by Authorized body, carrying out their examination for compliance of the provisions contained therein with requirements of the current legislation.

The relations between the insurer and the insured in contractual insurance obligations have a two-level structure. Firstly, the general terms of insurance are contained in rules of insurance. Secondly, its specific (direct) conditions are determined when concluding an insurance contract in accordance with the current legislation. Concluding an insurance contract, the parties have the right to independently determine its terms

4 Закон України «Про особливості страхування сільськогосподарської продукції з державною підтримкою» від 9 лютого 2012 р. № 4391-VI // Відомості Верховної Ради України. 2012. № 41. Ст. 491.

5 Суб'єкти цивільного права / За загальною редакцією академіка АПрН України Я. М. Шевченко. Х.: Харків юридичний, 2009. С. 445.

${ }^{6}$ Страхування: підручник / Керівник авт. колективу і наук. ред. С. С. Осадець. Вид. 2-ге, перероб. $\mathrm{i}$ доп. К.: КНЕУ, 2002. С. 207. 
(content) without permission of a significant change in provisions contained in insurance rules.

According to Part 1 of Article 3 of the Law of Ukraine "On Insurance" and Part 2 of Article 984 of the Civil Code of Ukraine, the insured are legal entities and legally capable natural persons who have concluded insurance contracts with insurers or are insured persons in accordance with the legislation of Ukraine. Moreover, foreigners, stateless persons and foreign legal entities use the right to insurance protection on equal terms with citizens and legal entities of Ukraine at the territory of Ukraine. However, in L. K. Kinashchuk's opinion, such a definition is too narrow, since legal entities and natural persons who have an insurance interest and enter into relations with insurers according to law provisions, participate in the creation of an insurance fund by paying contributions and have the right to compensation in the event of an insured event should be recognized as the insured ${ }^{7}$. Similar opinions are expressed by other scientists who distinguish two main features characterizing the insured: the first one is the legal capacity of the insured, and the second one is in mandatory presence of insurance interest of the insured ${ }^{8}$.

O. A. Shergunova emphasizes on the following special features of the insured as a participant in insurance relations: 1) it is a person who is always interested in insurance (has an interest in insurance), 2) it is a person who insures a certain interest (personal or a third person) as a insurance object, 3) it is a party to the insurance contract, 4) in case of insured event occurrence, acts as a creditor, regardless of whether the insured is a beneficiary or not; 5) throughout the term of the insurance contract validity the insured bears the burden of non-occurrence of an insured event ${ }^{9}$.

The insured interest of the insured can be characterized by the following features: a) interest in preserving the object of insurance protection - life, health, working capacity, property, civil liability; b) interest in non-occurrence of the insured event, namely, that in the future no expenses related to compensation for damage caused to life, health, property of the insured, insured person or third party under the

\footnotetext{
${ }^{7}$ Кінащук Л. Л. Страхове право: підручник. К.: Атіка, 2007. С. 72.

${ }^{8}$ Гражданское право: учебник. В 4-х т. Т. 1 / Под ред. Е. А. Суханова. М., 2008. С. 201; Худяков А. И. Страховое право. СПб.: Издательство Р. Асланова «Юридический центр Пресс», 2004. С. 251.

${ }^{9}$ Шергунова Е. А. Гражданско-правовое положение основных участников страховых отношений: автореф. дис. ... канд. юрид. наук: 12.00.03. Курск, 2013. С. 23.
} 
liability insurance contract arise; c) taking of active actions aimed at obtaining future monetary compensation to cover sudden expenses, by concluding an insurance contract.

In participation of natural persons in contractual insurance relations as the insured and a party to the insurance contract, the presence of civilian legal capacity in full scope is typical. In national doctrine of private law, a legal capacity of a natural person includes: capacity for concluding transactions, tort capacity, trans legal capacity, business capacity, test mental capacity, family capacity and cyber capacity as the ability of a person to be an active participant in IT-related relations (to be a member of social networks, to take part in interactive actions, etc.) ${ }^{10}$. It should be noted that the invalidity of transactions, parties to which are natural persons, is based on the same criteria as general rules of legal capacity occurrence, namely: age and mental attitude to actions taken. If the insured natural person during validity of an insurance contract based on a court decision is considered to have limited legal capacity or to be incapable, such person's rights and obligations of the insured are exercised, respectively, with the consent of the trustee or guardian. At the same time, any natural person can be an insured person, defined by the insured in the insurance contract.

Thus, the insured as a party to an insurance contract is a legal entity or legally capable natural person who voluntarily or on the demand of the law concludes an insurance contract with the insurer for the purpose of insurance protection of own legitimate interests or interests of another person related to life, health, working capacity, pension, possession, use and disposal of property, indemnification of damage caused to a natural person, person's property or property of a legal entity, in their favor or in favor of third parties.

The replacement of the insured in contractual insurance relations is carried out in accordance with provisions of the Law of Ukraine "On Insurance". So, according to Article 22 of the Law of Ukraine "On Insurance" in case of death of the insured, a natural person who concluded a contract of property insurance, the rights and obligations of the insured are transferred to persons who inherited the property. In other cases, the

\footnotetext{
${ }^{10}$ Харитонов С. О., Харитонова О. І. Актуальні проблеми цивільної правосуб'єктності учасників інформаційно-комунікаційних відносин // Актуальні проблеми приватного права: матеріали XVII наук.практ.конф., присвяч. 97-й річниці 3 дня народж. док. юрид. наук, проф. В. П. Маслова (Харків, 22 лютого 2019 р.). Харків: Право, 2019. С. 128.
} 
rights and obligations of the insured may be transferred to another natural person or legal entity only with the consent of the insurer, unless otherwise provided by an insurance contract (Part 1 of Article 994 of the Civil Code of Ukraine). For example, in case № 29/138-09, on the claim of "Yu"LLC to CJSC "F" on obligation to execute the conditions of the voluntary insurance contract of motor vehicles and debt collection and moral damage, the Supreme Economic Court of Ukraine supported a legal position of the Economic Court of Appeal and remained unchanged the resolution of the court of appellate instance by its decision on December 17, 2009, indicating that rights and obligations of the insured can be transferred to another natural person or legal entity only with a consent of the insurer ${ }^{11}$.

If a legal entity, the insurer, is terminated and its successors are established, then according to Part 1 of Article 995 of the Civil Code of Ukraine and Article 23 of the Law of Ukraine "On Insurance", rights and obligations of the insured are transferred to the successors. However, this rule applies to cases when a legal entity is terminated in the form of reorganization (Articles 106-109 of the Civil Code of Ukraine). Winding up of the insured-legal entity (Article 110 of the Civil Code of Ukraine) entails the termination of the insurance contract.

Some researchers consider the insured as a "weak" party in contractual insurance relations as well as consumers of insurance services and, accordingly, combine the issues of exercise and protection of their rights with exercise and protection of consumer rights. The adoption by the Cabinet of Ministers of Ukraine of the Concept for Protection of Consumer Rights of Non-Banking Financial Services, ${ }^{12}$ including insurance services, facilitates this to a certain extent. In connection with this, the question arises about the possibility of extending to the insurance relations the norms of the Law of Ukraine "On Protection of Consumer Rights". In connection with this, a question about possibility of extending the norms of the Law of Ukraine "On Protection of Consumer Rights" to

\footnotetext{
${ }^{11}$ Постанова Вищого господарського суду України від 17.12.2009 р. у справі № 29/138-09. URL: http://pravoscope.com/act-postanova-29-138-09-shvec-v-o-17-12-2009-inshij-majnovij-spir-s (дата звернення: 20.04.2019).

12 Розпорядження Кабінету Міністрів України «Про схвалення Концепції захисту прав споживачів небанківських фінансових послуг в Україні» від 3 вересня 2009 р. № 1026-р. // Офіційний вісник України. 2009. № 69. С. 30.
} 
insurance relations arises ${ }^{13}$. Thus, according to one view, the Law of Ukraine "On Protection of Consumer Rights" does not cover legal relations arising from the Law of Ukraine "On Compulsory Insurance of Civil Liability of Owners of Land Transport Vehicles", since it is aimed at protecting life and health and property of third parties, while the Law of Ukraine "On Protection of Consumer Rights" regulates relations arising from contracts aimed at satisfying solely personal needs and legal relations on voluntary property insurance ${ }^{14}$. In accordance with the opposite legal view, since the insurer's activities subject to definition of service and an executor, contained in Part 1 of Article 1 of the Law of Ukraine "On Protection of Consumer Rights", then, if an insurance contract is aimed at satisfying personal needs of the insured natural person, such legal relations are regulated by the Law of Ukraine "On Protection of Consumer Rights" in the part not regulated by a special $\operatorname{law}^{15}$. This conclusion also applies to property insurance contracts, where the insured are natural persons, and relations are aimed at protecting the personal property interests of the insured or another person specified in the contract. This point of view is also enshrined in paragraph 2 of the Resolution of the Plenum of the Supreme Court "On practice of consideration of civil cases in claims for consumer rights protection", which states that, since the Law of Ukraine "On Protection of Consumer Rights" does not define certain limits of its effect, courts should keep in mind that relations regulated by it include, among others, those arising from insurance contracts ${ }^{16}$. By joining the second point of view, we believe that legislation on consumer protection is applied subsidiary in part not regulated by insurance law as a special law concerning regulation of relations with participation of insurance service consumers.

The issue of consumer rights protection is a subject of regulation in a range of international legal documents. One should distinguish the Consumer Protection Charter, adopted by the 25th session of the Consultative Assembly of the European Union on May 17, 1973

\footnotetext{
13 Закон України «Про захист прав споживачів» від 12 травня 1991 р. № 1023-ХІІ // Відомості Верховної Ради УРСР. 1991. № 30. Ст. 379.

14 Мельник 3. П., Романюк Я. М. Судова практика розгляду цивільних справ, що виникають 3 договорів страхування // Вісник Верховного Суду України. 2011. № 8 (132). С. 24.

15 Жайворонок Т. Є., Павловська С. В. Судова практика розгляду цивільних справ про захист прав споживачів // Вісник Верховного Суду України. 2013. № 1 (149). С. 32.

16 Постанова Пленуму Верховного Суду України «Про практику розгляду цивільних справ за позовами про захист прав споживачів» від 12 квітня 1996 р. № 5. URL: http://zakon1.rada.gov.ua/laws/ show/v0005700-96 (дата звернення: 25.04.2019).
} 
(resolution 543) ${ }^{17}$, and "Guiding Principles for Protection of Consumer Interests", approved by The General Assembly of the United Nations on April 9, 1985 (resolution 39/248) ${ }^{18}$. The provisions of these international documents were reflected in the Law of Ukraine "On Protection of Consumer Rights" as well, according to clause 22 of Article 1 of which a consumer is a natural person who purchases, orders, uses or intends to purchase or order products for personal needs not directly related to entrepreneurial activity or performance of duties of a hired employee. As it follows from the definition of a consumer that the consumer can be only a natural person who is a participant in civil relations (thus, it can be both citizens of Ukraine, foreigners and stateless persons). However, the main criterion for distinguishing the consumer from other participants in civil legal relations is the goal of acquiring products aimed at satisfying personal needs not directly related to entrepreneurial activity or performance of duties of a hired employee. O. Yu. Cherniak, studying the consumer's civil legal status in the context of Ukrainian legislation adaptation to the EU legislation, notes that in the EU law a person who purchases good (services) for use but not with the purpose of commercial or professional activity is recognized as a consumer ${ }^{19}$. Taking into account judicial practice, a consumer is considered from the point of view of a weak party to a contract ${ }^{20}$.

The interpretation of concept of a "consumer" as a natural person is not solely Ukrainian, but corresponds to the widespread European practice on this issue. Thus, according to Article 2 of Council Directive 93/13/EEC on 5 April, 1993 on unfair terms in consumer contracts, ${ }^{21}$ the consumer is any natural person who, in contracts governed by this Directive, is acting for purposes outside personal professional activity, business, and profession. At the same time this EU Directive is based on consumer definition given in Rome Convention on the Law applicable to contractual

\footnotetext{
17 Дудла І. О. Захист прав споживачів: навчальний посібник. К.: Центр учбової літератури, 2007. C. 39.

i8 Керівні принципи захисту інтересів споживачів. Резолюція 39/248 Генеральної Асамблеї ООН

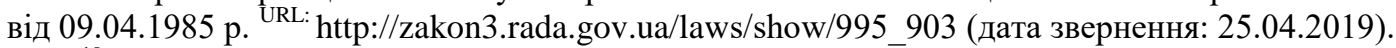

${ }^{19}$ Черняк О. Ю. Цивільно-правовий статус споживача у контексті адаптації законодавства України до законодавства Свропейського Союзу: автореф. дис. ... канд. юрид. наук: 12.00.03; НДІ приватного права і підприємництва НАПрН України. К., 2011. С. 7.

${ }^{20}$ Campbell P. The Consumer Interest: a Study in Consumer Economics. N. Y., 1976. P. 2.

21 Директива Ради 93/13/СЕС від 5.04.1993 р. «Щодо несправедливих умов споживчих договорів //

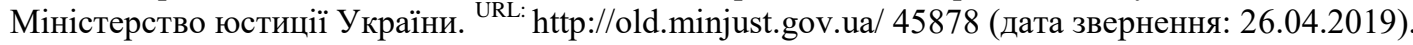


obligations of $1980^{22}$, as a person acting outside own commercial activity or profession. We should note that when comparing this definition with the definition of the Law of Ukraine "On Protection of Consumer Rights", granting a consumer status to a person does not depend on the nature of their actions performed, but in the Law the consumer must necessarily order, acquire, and use something or intend to do so. Moreover, the Directive, unlike the Law, provides for a limited number of non-consumer goals, while all others are considered to be consumer ones. Therefore, according to the Directive, much more people will be subject to consumer protection $^{23}$.

The consumer's legal status is a special legal status of a natural person, who purchases (intends to purchase), or uses products solely for personal needs, which are not directly related to entrepreneurial activity of this natural person or this person's duties of hired employee, enshrined in legislation on protection of consumer rights ${ }^{24}$. As O. Yu. Cherniak notes, specificity of the consumer's legal status is manifested in two peculiarities: a moment of occurrence of such status in a person and in giving the consumer additional legal opportunities in the framework of a special legal status. Taking it into account, the author determines the structure of the consumer's special civil-law status, including the following elements: a special civil legal capacity, consisting in the unity of special legal capacity and ability, as well as personal rights and responsibilities $^{25}$. At the same time, in order for relations to be covered by the Law of Ukraine "On Protection of Consumer Rights", it is necessary to take into account the legal status of another subject of legal relations from whom a consumer purchases, orders, uses or intends to purchase or order products, that is, the executor or the seller, who, in accordance with clause 3, 18 part 1 of Article 1 of this Law are subjects of economic activity. The said Law does not cover relations where a manufacturer and a seller of goods, an executor of works and a services provider is a natural

\footnotetext{
22 Convention on the Law Applicable to Contractual Obligations of 19 June $1980 / /$ Treaty Series. Vol. 1605. N. Y., 1997. P. 59-156.

${ }^{23}$ Milovska N. Legal status of the consumer of insurance services under the law of Ukraine // Jurnalul juridic naţional: teorie şi practică. 2017. № 4 (26). P. 84.

${ }^{24}$ Ханик-Посполітак Р. Ю. Захист прав споживачів фінансових послуг в Україні: правовий аналіз. К.: НУ «Києво-Могилянська академія», 2011. С. 21.

25 Черняк О. Ю. Цивільно-правовий статус споживача у контексті адаптації законодавства України до законодавства Свропейського Союзу: автореф. дис. ... канд. юрид. наук: 12.00 .03 ; НДІ приватного права і підприємництва НАПрН України. К., 2011. С. 8.
} 
person who is not an entrepreneur, as well as cases where an acquirer of goods, a user of services is enterprises, institutions, and organizations ${ }^{26}$.

Currently, there is no legal definition of concept of "consumer of insurance services". Professional legal literature also does not contain definitions of this concept, in contrast to works in the economic field ${ }^{27}$. Insufficient determinacy of legal status of the consumer of insurance services creates obstacles in the protection of their rights, which is confirmed by judicial practice of considering civil cases arising from insurance contracts ${ }^{28}$. It should be noted that from the time of legislation on consumer protection occurrence, it was oriented, first of all, on regulation of property relations, within which the needs of consumers in obtaining the goods themselves are satisfied. Thus, G. A. Osetynska in her dissertation research points out that the overwhelming part of provisions of consumer law institution has not received proper scientific justification, in particular concerning protection of consumer rights in the field of providing services ${ }^{29}$.

The phrase, in particular, "a consumer of financial services" is used in the Law of Ukraine "On Financial Services and State Regulation of Markets of Financial Services" 30 . Thus, according to clause 7, Part 1 of Article 1 of this Law, the customers of financial services belong to participants of financial service market. However, there is no legal definition of "a customer of financial services" in the law. It is worth noting that in accordance with the plan of measures concerning implementation of the Concept for Protection of Consumer Rights of Non-Banking Financial Services of Ukraine ${ }^{31}$, the National Commission on State Regulation in the Field of Markets of Financial Services (hereinafter - Natsfinposlug) was obliged to implement a range of

\footnotetext{
${ }^{26}$ Жайворонок Т. Є., Павловська С. В. Судова практика розгляду цивільних справ про захист прав споживачів // Вісник Верховного Суду України. 2013. № 1 (149). С. 19.

27 Гаманкова О. О. Ринок страхових послуг України: сутність, тенденції та шляхи розвитку: автореф. дис. ... док. екон. наук: 08.00.08; ДВНЗ «Київ. нац. екон. ун-т ім. В. Гетьмана». К., 2010. 33 с.

28 Мельник 3. П., Романюк Я. М. Судова практика розгляду цивільних справ, що виникають 3 договорів страхування // Вісник Верховного Суду України. 2011. № 8 (132). С. 12.

${ }_{29}$ Осетинська Г. А. Цивільно-правовий захист прав споживачів за законодавством України: автореф. дис. ... канд. юрид. наук: 12.00.03; Київський національний ун-т ім. Тараса Шевченка. К., 2006. C. 2 .

30 Закон України «Про фінансові послуги та державне регулювання ринків фінансових послуг» від 12 липня 2001 р. // Відомості Верховної Ради України. 2002. № 1. Ст. 1.

${ }^{31}$ Розпорядження Кабінету Міністрів України «Про затвердження плану заходів щодо реалізації Концепції захисту прав споживачів небанківських фінансових послуг в Україні» від 20 січня 2010 р. № 135-р. // Урядовий кур’єр. 2010. № 25.
} 
measures including settlement of the issue for determination of concept "a consumer of financial services". In the draft suggested by Natsfinposlug "On approval of the Draft Law of Ukraine "On amendments to some legal act of Ukraine for improvement of state regulation and supervision of markets of non-banking financial services" on October $30,2018^{32}$ it was proposed to amend Part 1 of Article 1 of the Law of Ukraine "On Financial Services and State Regulation of Market of Financial Services with new clauses $7^{1}$ and $7^{2}$ with the following meaning: " $7^{1}$ ) the consumer of financial services (consumer) - is a natural person who receives, has intentions and in accordance with the law may receive a financial service to meet needs not related to entrepreneurial, independent professional activities or performance of duties of a hired employee; $7^{2}$ ) the customer a natural person (including the consumer), a natural person-entrepreneur or legal entity which receives, has intentions and in accordance with the law may receive a financial service. In turn, the phrase "a consumer of insurance services" is used in the draft Law of Ukraine "On Insurance" on December 19, 2011 33 . This draft contains a new version of the Law of Ukraine "On Insurance" and was adopted in the first reading on May 22, 2012. In addition, Article 94 and Article 95 of this draft contain the phrase "a consumer of insurance services", but Article 1 giving determination of concepts used in the draft, does not contain such phrase.

According to G. O. Ilchenko, a consumer of insurance services is a legally capable natural person who, on the basis of a concluded contract with this person or by another person with the insurer, obtains an insurance service necessary to meet personal needs not directly related to entrepreneurial activity of that natural person or that person's performance of duties as a hired employee ${ }^{34}$. However, such definition is not accurate enough, since, as it follows from it, only the insured acting as a consumer of insurance services is a participant of insurance relations. In addition, an

\footnotetext{
32 Проект розпорядження Національної комісії 3 державного регулювання у сфері ринків фінансових послуг «Про схвалення проекту Закону України «Про внесення змін до деяких законодавчих актів України щодо вдосконалення державного регулювання та нагляду за ринками небанківських фінансових послуг» від 30.10 .2018 p. № 1913 . URL: https://www.nfp.gov.ua/ua/ Proektyrehuliatornykh-aktiv/26494.html (дата звернення: 29.04.2019).

${ }^{33}$ Проект Закону України «Про внесення змін до деяких законів України та виклад Закону України «Про страхування» у новій редакції від 19.12.11 p. № 9614. URL: http://zakon.rada.gov.ua/rada/show/482617 (дата звернення: 29.04.2019).

${ }^{34}$ Ільченко Г. О. Цивільно-правовий захист прав споживачів страхових послуг: дис. ... канд. юрид. наук: 12.00.03. К.: НДІ приватного права і підприємництва імені академіка Ф. Г. Бурчака НАПрН України, 2016. С. 73.
} 
insurance contract is concluded by the insurer only with the insured person, and not with another person, as indicated in the author's definition. However, property interest may be insured by such contract for the insured personally and for another person, as well as the insurance contract may be concluded both in favor of the insured person and another person.

It is worth noting that the consumer of insurance services, as it follows from the Law of Ukraine "On Protection of Consumer Rights", may not only be a natural person who acquires or orders a service for personal needs, but also a natural person who uses such service for these goals (for example, the insured person or beneficiary). Concluding an insurance contract in favor of the third person, the insured person is exactly the user (consumer) of the insurance service, provided that the insurance contract is aimed at satisfying their personal needs. Moreover, according to the letter from the Supreme Court of Ukraine of July 19, 2011, the insurance contract gives the third person the right to demand from the insurer to make an insurance payment in favor of this third person, that is, it gives the beneficiary the rights of the insured party, but does not impose on beneficiary obligations of the latter ${ }^{35}$.

Therefore, the consumer of insurance services is a capable natural person, who concludes an insurance contract with the insurer, as well as the natural person in whose interests and in whose favor the insurance contract is concluded, and who receives the insurance service necessary for satisfaction of personal needs, not directly related to the entrepreneurial activity of this natural person or the performance of natural person's duties as a hired employee.

The process of providing an insurance service combines the unity, confrontation and dependence of interests of the parties "insurer - the insured". This can be explained by necessity for a balance between ensuring the financial stability of the insurer on the one hand and providing insurance protection to the insured, on the other.

The insurers are interested in minimization of expenses, including at the expense of reduction of insurance payment, and the insured persons are interested in obtaining insurance protection in full. It is possible to add to these features as well that in most cases the consumer of insurance

\footnotetext{
35 Мельник 3. П., Романюк Я. М. Судова практика розгляду цивільних справ, що виникають 3 договорів страхування // Вісник Верховного Суду України. 2011. № 8 (132). С. 21.
} 
services does not have special knowledge in the field of providing this type of services. Therefore, as L. M. Sokil appropriately notes, it is unprofessional status of the consumer and asymmetry of the parties to the insurance contract that are those additional arguments, determining the need for an additional protection mechanism of this category of the insured $^{36}$. And this mechanism should be based, first of all, on the right and obligations of the parties to the insurance contract.

Since the insurance contract is bilateral, each of its parties has rights and obligations. It is important that the rights of one party relate to the obligations of the other party in such a way that the relevant obligation of the insurer corresponds to the relevant right of the insured and vice versa. Depending on the sources of legal regulation, the rights of consumers of insurance services can be classified into: 1) the rights enshrined in laws (the Civil Code of Ukraine, the Law of Ukraine "On Insurance", etc.), 2) the rights enshrined in by-laws (Decrees and Orders of the Cabinet of Ministers Ukraine, the Decree of the National Commission on State Regulation in the Field of Markets of Financial Services); 3) rights enshrined in local acts (Rules of Insurance); 4) rights enshrined in the insurance contract.

The general rights and obligations of the parties to the insurance contract are provided for by the Civil Code of Ukraine (Articles 988, 989) and the Law of Ukraine "On Insurance" (Articles 20, 21). Thus, the ensured has the right to: choose an insurer for insurance contract conclusion; to conclude an insurance contract with the insurer on third parties' insurance (insured persons) only with their consent, except for the cases stipulated by current legislation; when concluding an insurance contract, appoint a natural person or legal entity (beneficiaries) to receive an insurance payment, unless otherwise provided for in the insurance contract; before insured event occurrence, replace the beneficiary appointed under the insurance contract, except for the liability insurance contract, by another person, informing the insurer about it in writing. It should be taken into account that the respective right of the insured to replace the beneficiary with another person can not be realized after the beneficiary has fulfilled any of obligations under the insurance contract or has submitted to the insurer a claim for the insurance payment; increase the amount of insurance sum with the subsequent recalculation of amount

\footnotetext{
${ }^{36}$ Сокіл Л. М. Про необхідність уточнення поняття «споживач страхових послуг» // Фінанси, облік і аудит. 2012. № 19. С. 183.
} 
of the insurance payment during validity term of the insurance contract; at insured event occurrence, receive an insurance payment in a manner and in terms established by rules and insurance contract; early terminate the effect of the insurance contract under conditions stipulated by insurance rules.

In addition, analyzing obligations of the insurer, provided in Article 20 of the Law of Ukraine "On Insurance", it is possible to distinguish the following rights of the insured: the right of the insured to be familiarized with conditions and rules of insurance; the right to timely payment of insurance payments or insurance indemnity; the right to receive a penalty (fine) in case of untimely insurance payments; the right for indemnification of expenses incurred by the insured in case of insured event occurrence in respect of prevention or reduction of losses, if it is provided by the terms and conditions of the contract, the right of the insured in case of taking measures that reduced insurance risk or increased property value, to renew the insurance contract, the right to non-disclosure of information of the insured about the insured and their property status, except in cases specified by law, etc.

Taking into account the dynamics of insurance relations, the rights and obligations of the parties to the insurance contract can be divided into four groups: 1) rights and obligations arising at the stage of insurance contract conclusion; 2) rights and obligations arising during the insurance contract validity; 3) rights and obligations arising after insured event occurrence; and 4) rights and obligations arising from the improper performance of the insurance contract.

Characterizing the rights of the insured, including the rights of consumer of insurance services, it should be noted that, in particular, at the stage of concluding an insurance contract, the insured has the right to necessary, accessible, reliable and timely information about the insurance service, providing possibility of its informed and competent choice. Thus, Western authors, analyzing judicial practice, indicate that using the concept of "consumer", the courts should determine the degree of consumer's information awareness ${ }^{37}$. The exercise of the right of the insured to information about an insurance service is a precondition for existence and possible exercise of other rights of the insured. Provision of such information, as a rule, must precede the conclusion of an insurance

\footnotetext{
${ }^{37}$ Incardona R., Poncibo C. The Average Consumer, the Unfair Commercial Practices Directive, and the Cognitive Revolution // Journal of Consumer Policy. 2007. Vol. 30. P. 30.
} 
contract, so, information must be provided before the service purchase ${ }^{38}$. This right gives the opportunity to identify such subject as a "potential consumer" who has an interest in purchasing an insurance service but is not obliged to purchase $\mathrm{it}^{39}$. If there is such interest, a consumer has the right to receive information about the insurance service. Thus, we join the point of view of scientists who prove the pre-contractual legal nature of consumer rights to information on products (in this case, an insurance service $)^{40}$. In addition, the right of the insured to information does not vanish after insurance contract conclusion; it exists during all the validity term of the contract.

During the insurance contract validity, the ensured, including the consumer of insurance services, has the right to: proper quality of service; the right not to disclose information about the customer and customer's property status, except in cases established by law; the right to renew the contract in case of reduction of the insurance risk or increase of the property value; the right of the insured to initiate the application amendments and additions to this agreement; the right to receive a duplicate of the insurance contract in case of its loss; the right to terminate the contract ahead of time in accordance with the conditions specified by the contract and Insurance rules; the right to appoint beneficiaries to receive insurance payments or to change them before the occurrence of an insured event, etc.

One of the rights of the insured, which can be exercised at this stage of contractual relations, in particular property insurance, is the right to declare to the insurer about abandonment of insured rights to all insured property (abandon) and to receive a full insurance sum in case of loss or death of property. Such right of the insured is stipulated in Article 271 of the Merchant Shipping Code of Ukraine (hereinafter referred to as the MSC of Ukraine), according to which the insured can claim to the insurer to abandon own rights to all insured property (abandon) and to receive the full insurance sum in the following cases: loss of a missing ship; economic inexpediency of rebuilding or repairing the insured vessel;

\footnotetext{
${ }^{38}$ Ільченко Г. О. Цивільно-правовий захист прав споживачів страхових послуг: дис. ... канд. юрид. наук: 12.00.03. К.: НДІ приватного права і підприємництва імені академіка Ф. Г. Бурчака НАПрН України, 2016. С. 78.

${ }^{39}$ Hondius E. The Notion of Consumer: European Union versus Member States // Sydney Law Review. 2006. Vol. 28. No. 1. P. 94.

40 Черняк О. Ю. Цивільно-правовий статус споживача у контексті адаптації законодавства України до законодавства Європейського Союзу: автореф. дис. ... канд. юрид. наук: 12.00.03; НДІ приватного права і підприємництва НАПрН України. К., 2011. С. 9.
} 
economic inexpediency of elimination of damage or delivery of insured goods to their destination; seizure of a ship or cargo insured against such danger if the seizure lasts more than two months. If, upon receipt of an indemnity from the insurer, it appears that the ship has not lost or the seized vessel or cargo is released, the insurer may require that the insured, having left the property, has returned the insurance indemnity, with the exception of partial indemnity if the insured has suffered from it. The application to abandon must be made to the insurer within six months from expiration of terms (occurrence of circumstances), loss of property ${ }^{41}$. With expiration of six-month period, the insured loses the right to abandon, but may claim damages on general grounds (Article 272 of the MSC of Ukraine)

After insured event occurrence, the insured has the right to: timely payment of insurance payment or insurance indemnity; the right to indemnification of expenses incurred by the insured at the insured event occurrence in order to prevent or reduce losses, if it is provided by terms and conditions of the contract ${ }^{42}$. In case of improper performance of the insurance contract, the insured as a party to the insurance contract has a right to judicial protection of their violated, unrecognized or disputed rights or interests, the right to obtain a penalty (fine) in case of untimely insurance payments, etc.

In addition, it should be noted that in legal doctrine there are various grounds for the classification of consumer rights, including the rights of consumers of insurance services. Thus, the rights of consumers listed in Article 3 of the Law of Ukraine "On Protection of Consumer Rights" I. O. Dudla classifies, depending on the area of their implementation, on general organizational rights, implementation of which is based on interaction with state authorities (state protection of consumer rights, consumer associations in public organizations, appeal to court and other authorized bodies), and consumer rights related to relations between them and subjects of entrepreneurial activity selling goods (work, services) (right to the proper quality of goods (works, services) and services; the right to safety of goods (works, services), the right to necessary, available, reliable and timely information on products; indemnification of damages caused by goods (works, services) of improper quality as well as property

\footnotetext{
${ }^{41}$ Кулина Ю. А. Договір страхування каско автотранспортних засобів у цивільному праві України: автореф. дис. ... канд. юрид. наук: 12.00.03; Нац. ун.-т «Одеська юридична академія». Одеса, 2013. С. 7.

42 Цивільне право України. Особлива частина: підручник / За ред. О. В. Дзери, Н. С. Кузнєцової, Р. А. Майданика. 3-тє вид., перероб. і доп. К.: Юрінком Інтер, 2010. С. 324.
} 
and moral damage caused by dangerous products ${ }^{43}$. In our opinion, the rights of insurance service customers depending on regulatory action of civil law acts which establish and regulate relevant relations, can be divided into: universal (general), existing of which is established by the Law of Ukraine "On Protection of Consumer Rights", and special: the right of insurance service consumers provided by insurance legislation and an insurance contract.

At the same time, subjective right, as it is noted in legal literature, can not be successfully implemented outside the context of a legal obligation, since it loses essentially its content and meaning in other case. It is subjective rights and obligations that are mutually determining (correlative), linking or placing subjects in legal dependence on each other and thus form legal relations ${ }^{44}$. Thus, as it follows from Article 989 of the Civil Code of Ukraine and Article 21 of the Law of Ukraine "On Insurance", obligations of the insured under the insurance contract are: timely contribution of insurance payments; at conclusion of the insurance contract providing the insurer with information on all the known circumstances, which are essential for evaluating the insurance risk, and further informing the insurer of any change in the insurance risk; insurer's notification on other valid insurance contracts concerning the object of insurance. According to Article 989 of the Civil Code of Ukraine, if the insured has not informed the insurer that the object is already insured, a new contract is invalid; taking measures to prevent and reduce losses incurred as a result of an insured event; notification of the insurer about the insured event occurrence within the period stipulated by insurance conditions. The terms and conditions of the insurance contract can also include other obligations of the insured.

The main obligation of the insured person is to pay for an insurance service (insurance payment, premium) in the amount established by the contract (Part 1 of Article 989 of the Civil Code of Ukraine). In turn, the insurer has the right to reduce the amount of insurance payments, encouraging the insured to take measures aimed at preventing the insured event occurrence, as well as increase the amount of insurance payments to the insured persons who caused the insured events. A lawmaker associates the entry into force of the insurance contract and the beginning of the

\footnotetext{
43 Дудла І. О. Захист прав споживачів: навчальний посібник. К.: Центр учбової літератури, 2007. C. $23-25$.

${ }^{44}$ Надьон В. В. Суб'єктивний обов'язок як елемент змісту цивільних правовідносин: монографія. Харків: Право, 2017. С. 163.
} 
insurance protection with making the first insurance payment (Article 983 of the Civil Code of Ukraine). Protection is provided through an insurance fund, formed from insurance premiums paid by the insured.

In accordance with Part 2 of Article 997 of the Civil Code of Ukraine, if the insured has delayed the insurance payment and did not pay it within 10 working days after the insurer had filed a written request for the insurance payment, the insurer can refuse from the insurance contract, unless otherwise specified in the contract. Article 39 of the Law of the Federal Republic of Germany on the insurance contract ${ }^{45}$ also explicitly states the necessity for the insurer before refusing of the contract in connection with the delay in paying the premium to remind the insured of the necessity of payment, and if the insured ignore this reminder it is quite rightly to give the insurer the right to refuse from the contract. A similar norm is contained in Article 20 of the Swiss Act on Insurance Contract ${ }^{46}$. The norm of Article 1901 of the Civil Code of Italy ${ }^{47}$ contains the provision according to which the insurance contract remains valid for 15 days after the delay in payment of the next contribution.

Article 997 of the Civil Code of Ukraine provides for possibility of returning the insurance payments to the insured previously paid by them. Thus, the insurance payments paid, are fully returned to the insured by the insurer, if the refusal from the contract by the insured is caused by violation of terms and conditions of the contract by the insurer, as well as if the insurer has refused from the insurance contract (except for the life insurance contract). In turn, insurance payments for the period remaining before the expiration of the insurance contract are returned to the insured by the insurer if the insured has refused from the insurance contract (except for the life insurance contract), and if the insurer's refusal from the contract is caused by non-performance of the conditions of the insurance contract by the insured. In addition, the possibility of returning paid insurance payments to the insured, in particular, under the contract of universal life insurance within the limits of insurance reserve, formed before the termination of the insurance contract, is stipulated in Article 28 of the Law of Ukraine "On Insurance". This amount is called a cash

\footnotetext{
45 Закон ФРГ о страховом договоре от 30 мая 1908 г. // Страховое ревю. Апрель-май 1999 г., июньиюль 1999 г.

46 Швейцарский союзный закон о страховом договоре от 2 апреля 1908 г. / Пер. под ред. и с предисл. В. М. Нечаева. СПб., 1999.

47 Il Codice Civile Italiano: перев. с итал. И. Спринд-Ниманд. М., 2005. URL: http://www.sprind.ru/index.php?option=com_content\&view=article\&id=50\&Itemid=55\&lang=ru (Last accessed: 23.11.2018)
} 
surrender value. So, in case of early termination of the life insurance contract, the insurer pays a cash surrender value to the insured which is a property right of the insured under the life insurance contract. If the insurer's demand is caused by non-performance of conditions of the insurance contract by the insured, the cash surrender value is returned to the insured. The cash surrender value is the amount paid by the insurer in case of early termination of the life insurance contract and calculated mathematically on the day of termination of the contract depending on the period during which the life insurance contract was in force, according to the methodology, which undergoes examination in the Authorized body, is executed by actuary and is an integral part of life insurance rules. The Authorized body can establish requirements for the method of calculating the cash surrender value.

Insurance relations are based on a generally accepted principle of the highest trust of the parties, which involves providing complete information by parties (mostly the insured) about the object of insurance, including confidential one. Thus, at conclusion of the insurance contract, the insured is obliged to provide the insurer with information about all known circumstances known, which are essential for evaluating the insurance risk, and to keep the insurer informed of any changes in the insurance risk. Essential circumstances are considered such circumstances the knowledge about which would lead to a refusal to conclude a contract or significantly changed the conditions of payment for insurance services under the relevant contract. The composition of essential circumstances may vary in each specific case, depending on the features of an insurance object and nature of an event, for occurrence of which the insurance is carried out.

Taking into account the fact that a large number of circumstances can affect the amount and nature of risk, the insured as an unprofessional participant in insurance relations does not always know what to pay attention to, and what circumstances can be ignored. In turn, the insurer is a professional participant in insurance relations, whose risks are usually typified, and therefore the insurer, to a much greater extent than the insured, knows which circumstances are essential for evaluating the insurance risk. Therefore, negative consequences for the insured can take place only in case of deliberate failure to notify the insurer of circumstances known to the insured.

In general, circumstances that are substantially significant may include, for example, hidden deficiencies of the insured property, 
availability of security and signaling system in the premises where the property is located, or in car, other conditions for storage of property, health conditions of the insured natural person. Significant changes may include changes of the property owner (holder), nature of the property use, the removal or breakdown of signaling system, termination of protection of the insured object. The insured must notify the insurer of the circumstances which: 1) provide an opportunity to assume that the risk from which insurance is being made creates a greater threat to the insurance object than usually. For example, in case of insurance of a building from fire, such circumstance is wear of wiring in the premise; 2) give an opportunity to assume that the insured person will not follow the usual precautionary measures. For example, in property insurance, overestimated evaluation of the real property value can be this circumstance, and its owner, in addition to the interest in preservation of property, has actually speculative interest; 3 ) indicate that at the insured event occurrence, more damage will be done than it is usually done in such cases. Thus, in case of medical insurance, such circumstance is presence of allergic reactions in the history of the insured person; 4) indicate the so-called psychological risk. For example, in case of insurance in case of theft, such circumstances include the criminal past of the insured, in case of property insurance - the fact that earlier this property has already been insured, but the previous insurer refused to extend the contract ${ }^{48}$.

Assigning of such obligation to the insured person gives some authors the ground to consider an insurance contract as a type of a fiduciary contract, namely, the contract concluded on special trust (fiduciary trust) $^{49}$. However, a classical insurance contract is not a fiduciary transaction, since the insurer is not a possessor or an owner of the insured property. In turn, improper performance of such obligation can be a ground for refusal in making an insurance payment by the insurer at the insured event occurrence.

The insured is obliged to inform the insurer of other insurance contracts concluded on the object to be insured at the conclusion of the insurance contract (Part 3 of Article 989 of the Civil Code of Ukraine). Insurance can not be aimed at enriching the insured. Therefore, if an object is insured by several insurers, then the insurance indemnity paid by

\footnotetext{
${ }^{48}$ Фогельсон Ю. Б. Страховое право: теоретические основы и практика применения: монография. М.: Норма: ИНФРА М, 2012. С. 302.

${ }^{49}$ Гражданское право: учебник. В 4-х т. Т. 1 / Под ред. Е. А. Суханова. М., 2008. С. 301.
} 
all insurers can not exceed the amount of the damage caused. If the insured has not informed the insurer that the object of insurance is already insured, a new insurance contract is void (Part 3 of Article 989 of the Civil Code of Ukraine). In turn, for the conclusion of a reinsurance contract, the insurer is not obliged to notify the insured.

The insured is obliged to take measures to prevent damage caused by the insured event occurrence and to reduce them (Part 4 of Article 989 of the Civil Code of Ukraine). The indicated norm determines the time when obligation of the insured to take such measures appears - this is the moment of the insured event occurrence, namely, the moment when danger, from which the insurance is carried out, begins to cause damage. However, the insured can take measures reducing the likelihood of danger occurrence even before its occurrence. In this regard, the relevant measures are, in fact, not measures for reduction, but measures for prevention of losses. Thus, it is possible to distinguish the following measures taken by the insured in order to prevent or reduce losses: 1) preventive measures taken before occurrence of danger; 2) measures taken after occurrence of danger, but before the beginning of causing damage; 3) measures taken after the damage has begun to be inflicted.

It is worth noting that appropriate measures can be both actions and inaction (in particular, termination of operation of a vehicle damaged as a result of an accident, etc.). Such measures of the insured must meet the requirements of reasonableness (Article 3 of the Civil Code of Ukraine). Reasonableness in this case should be considered as actions taking into account those expenses necessary for their carrying out, in comparison with the amount of reduced losses. Reasonableness as a feature of measures to be taken by the party to reduce damage is also provided by Article III. - 3: 705 Draft Common Frame of Reference ${ }^{50}$ and Article 7.4.8. of the UNIDROIT ${ }^{51}$ principles, according to which reasonable measures may include taking certain actions, and keeping from actions that are unjustified under these circumstances. If the party, by

\footnotetext{
${ }^{50}$ Principles, Definitions and Model Rules of European Private Law. Draft Common Frame of Reference (DCFR). Prepared by the Study Group on European Civil Code and the Research Group on EC Private Law (Acquis Group). Based in part on a revised version of the Principles of European Contract Law, 2009. URL: https://www.law.kuleuven.be/personal/mstorme/2009_02_DCFR_OutlineEdition.pdf (Last accessed: 08.01.2019).

${ }^{51}$ Принципи международных ${ }^{\text {коммерческих договоров } У Н И Д Р У А ~ / ~ П е р . ~ с ~ а н г л . ~ А . ~ С . ~ К о м а р о в а . ~ М .: ~ М е ж д у н а р . ~ о т н о ш е н и я, ~} 2003$. $288 \mathrm{c}$.
} 
taking reasonable measures to reduce the losses, actually increases them, all costs are subject to indemnification ${ }^{52}$.

Along with obligation of the insured to take measures to prevent losses caused by the insured event occurrence, and to reduce them, the law provides for obligation of the insurer to cover expenses incurred by the insured in case of an insured event in order to prevent or reduce losses, if it is stipulated by the contract ( Part 4 of Article 988 of the Civil Code of Ukraine), as well as upon the request of the insured, in case of an insurer's measures for reducing insurance risk, to renew an insurance contract with the insured (Part 5 of Article 988 of the Civil Code of Ukraine, Article 20 of the Law of Ukraine "On Insurance"). At the same time, the insured demanding indemnification of losses incurred at the insured event occurrence with the purpose to prevent and reduce losses, has the necessity to prove the following circumstances: the purpose of the expenses incurred (they should be aimed at reducing the losses to be indemnified by the insurer), the necessity of the expenses incurred (some of costs might not be necessary to be made, but they have been made additionally); inevitability of causing damage.

The insured is obliged to inform the insurer about the insured event occurrence within the term established by the contract (Part 5 of Article 989 of the Civil Code of Ukraine). The claim of the insured for payment of insurance indemnity must be made in due time. Usually, under a voluntary insurance contract, the insured must notify the insurer in writing of the insured event occurrence within the term specified in the contract. Thus, in case of the insured event occurrence, the insured (a driver of the vehicle which caused the road accident) is obliged to inform the insurer about the insured event occurrence within three working days, give a written explanation about the circumstances of the accident and, if necessary, provide a vehicle for inspection and examination. In the absence of the insured, any adult member of family of the insured must apply with such statement. The obligation to notify the insured event occurrence may also be born by the beneficiary who must report about this if intends to take advantage of the right to receive an insurance indemnity.

In accordance with Part 1 of Article 13 of the Law of Ukraine "On peculiarities of insurance of agricultural products with state support" ${ }^{\prime 53}$ in

\footnotetext{
52 Діковська I. А. Співпраця - обов'язок сторін міжнародного приватного договору // Альманах міжнародного права. 2014. Вип. 5. С. 123.

53 Закон України «Про особливості страхування сільськогосподарської продукції з державною підтримкою» від 9 лютого 2012 р. № 4391-VI // Відомості Верховної Ради України. 2012. № 41. Ст. 491.
} 
the insured event occurrence, the insured must not later than 72 hours from the day of its occurrence notify the insurer in writing about it. In turn, in case of death or forced slaughter (destruction), traumatic damage or the disease of insured agricultural animals, poultry, rabbits, fur animals, bee colonies, aquatic bio-resources and livestock products, the insured is obliged to inform the insurer within 48 hours from the moment of detecting this event about it in writing and register the fact of their death, forced slaughter (destruction), traumatic injury or disease in the central executive body, which ensures the implementation of state veterinary policy in the field of veterinary medicine (central executive body, implementing the state policy in the field of fisheries). If the insured has not informed about the insured event occurrence, the insurer has the right to refuse to make an insurance payment ${ }^{54}$.

Current law does not provide for a complete list of obligations of the insured. It can be extended by other civil law acts ${ }^{55}$, as well as by an insurance contract concluded, if it is necessary for proper implementation of civil law relations.

Thus, the parties to the insurance contract - the insurer and the insured are compulsory participants of contractual insurance relations, having sufficient scope of civil legal capacity to exercise their rights and obligations under the insurance contract. At the same time, an insurance contract as well as any other civil law contract, has to take into account both counterparties: the insurer and the insured. Within any insurance contract the interest of each party can be satisfied only by satisfaction of interest of other party, and this, in turn, produces common interest to conclusion of the contract and its proper fulfillment.

Information about the author: Milovska N. V.

Candidate of Juridical Sciences, Assistant Professor at the Department of Special Legal Disciplines of the V. I. Vernadsky Taurida National University

\footnotetext{
${ }^{54}$ Цивільне право України: підручник: у 2-х т. / За ред. В. І. Борисової, І. В. Спасибо-Фатєєвої, В. Л. Яроцького. Харків: Право. 2011. Т. 2. С. 296.

${ }_{55}$ Шихов А. К. Страховое право: уч. пособие. 3-е изд., стер. М.: ЗАО Юстицин-форм, 2004. С. 109; Цивільне право України. Особлива частина: підручник / За ред. О. В. Дзери, Н. С. Кузнєцової, Р. А. Майданика. 3-тє вид., перероб. і доп. К.: Юрінком Інтер, 2010. С. 564.
} 